\title{
New District Creation in Uganda and Local Actors: Passive Recipients or Active Pursuers?
}

\author{
Tabaro Robert (Corresponding Author) \\ Kyambogo University \\ P.O Box 01, Kyambogo, Uganda \\ Katusiimeh Mesharch \\ Makerere University Business School, \\ P.O Box 1337, Kampala, Uganda
}

\author{
Nadia Molenaers \\ Institute of Development Policy and Management \\ Lange St.-Annastraat 7, B-2000 ANTWERP \\ Prinsstraat 13, B-2000 ANTWERP, Belgium
}

Received: March 26, 2018 Accepted: May 8, 2018 Online published: May 24, 2018

doi:10.5296/jpag.v8i2.13191 URL: https://doi.org/10.5296/jpag.v8i2.13191

\begin{abstract}
From the 1990s, Uganda embarked on a process of subdividing administrative units (districts) as part of the decentralization programme supposedly to bring services closer to the people. Literature has, however, shown that in most of the cases the process is used as a strategy by the incumbent president- Museveni for his political survival. As such, new district creation is seen as a process driven by central political elites. The role of local policy entrepreneurs (actors) has thus been given limited attention. Basing on thirty five elite interviews and document review, we established that local policy entrepreneurs do matter in policy change processes and can at times challenge the position of central political elites. Focusing on the new district of Sheema in western Uganda (split from 'mother' district of Bushenyi in 2010), we found out that president Museveni who initially 'opposed' the idea of a new district had to finally give in to peoples' demands. This was because local policy entrepreneurs in Sheema were determined, eager, highly motivated and smart in strategizing and forming alliances in
\end{abstract}


the pursuit of their goals. But also because the president feared vote loss as demands gained momentum towards the 2011 general elections.

Keywords: Uganda, new district creation, decentralization, local actors, policy entrepreneurs

\section{Introduction}

Since the 1990s, the number of Uganda's districts has more than tripled under President Museveni's rule ${ }^{1}$ (Grossman \& Lewis, 2014; Lewis 2014; Awortwi \& Helmsing, 2014a, 2014b). Scholarly research has mainly focused on the role of national actors and factors to explain the multiplication of districts (e.g. Green 2008, 2010; Niringiye, Bbaale \& Olowo, 2013; Awortwi \& Helmsing, 2014a, 2014b).

Most of the district creation studies have pointed at the incentives and interests of the national government - in particular the motivations of the president - in order to explain the proliferation of districts (Kasara, 2006; Green 2008, 2010; Awortwi \& Hemsling, 2014a, $2014 b$ ). Less attention has been paid to the role and motivations of local actors in the process of new district creation in Uganda (Grossman \& Lewis, 2014), which implicitly suggests that local actors are passive recipients of national level decisions. Though evidently the central government clearly has the final say in the creation of new districts, our main message and argument in this paper is that local actors can be quite active in using the creation of new districts as a window of opportunity to pursue their own interests. Our case shows that local 'activism' carried out by local 'policy entrepreneurs'(Kingdon 1984; Mintrom \& Norman, 2009) not just led to the creation of a new district but also - and maybe more importantly succeeded in overcoming President Museveni's initial opposition to the creation of the new district. More specifically, Bushenyi district had appeared in the media (Sengendo \& Ahimbisibwe, 2010; Namutebi, 2007) because President Museveni did not want to split up the district, while local actors especially from Sheema county were very eager to do so. Only a couple of years later, President Museveni shifted his position and local actors 'won' the creation of 'their' new district. This turn of events is not only important and relevant to better understand the complex drivers of district creation, it is also a way of getting a more in-depth insight into the national - local level interaction dynamics. National - local interactions are dynamic bargaining arenas and outcomes are not linear projections of power configurations. The dominant power of the national government can be, and as our paper shows, is challenged by local actors if and when these 'policy entrepreneurs' are highly motivated (either by greed or grievance) and if they are smart in strategizing and forming alliances in the pursuit of their goals.

This paper first delves into the literature of district creation rationales to set out national and local motivations and incentives for district creation. We then turn to the empirical part of the study where we unravel the national-local incentives which drove or constrained the Sheema district creation agenda. This reconstruction of incentives and bargaining dynamics is based on thirty five in-depth interviews with involved local actors and on secondary data. Finally

\footnotetext{
${ }^{1}$ From 34 districts in 1990, Uganda had 116 districts by 2017.
} 
we conclude.

\section{District Creation Rationales: National Actor Interests Prevail}

Mainstream literature on new district creation (e.g. Green 2008, 2010; Awortwi \& Helmsing, 2014a) emphasizes that the driving motivations of district creation are situated at the national/regime level because the bottom line incentive relates to the urge to secure the political survival of president Museveni and the National Resistance Movement (NRM). Securing political support can be achieved in two different ways:

1) to entice citizens to vote NRM (and hand out a number of benefits to the newly created districts and/or,

2) dividing the political opposition (hence to split those districts where the opposition is strong).

Entice citizens to vote NRM: Green (2008) argues that district creation has been primarily used by President Museveni to win elections and stay in power. In support of this, Awortwi and Helmsing (2014a) cite an example of Ngora county that when it was elevated to a district status in 2010, residents appreciated and voted NRM in 2011. As opposed to $27.4 \%$ of the votes Museveni got in 2006 when Ngora was still a county, this time, he got 48.2 percent. Grossman and Lewis (2014) support the above assertion and stress that there is evidence to show that elevating marginal counties to a status of a district in a given inter-election period leads to a significant increase in Museveni's vote share in those counties in the next presidential elections. Also, and not unimportant, they do not find evidence that Museveni suffers vote loss to rump counties-those that lost splinter counties in the period leading up to the presidential elections. To show that districts have been created to entice voters, Green (2010) shows that to gain maximum electoral advantage, in 2000 and 2005 Museveni chose to create new districts just a matter of months before presidential elections the following year, while in both the presidential elections of 1996 and 2006 he gave promises to create new districts after the election if citizens voted for him, leading to the creation of six new districts in 1997 and ten new districts in 2006 respectively.

Weakening the opposition: Importantly, literature has indicated that Museveni has created as many districts as possible in order to split the opposition power bases in opposition strongholds (Awortwi \& Helmsing, 2014a). For instance, the Northern and Eastern districts have been strong opposition areas partly because of the political instability in that part of the country which lasted for more than 20 years. As such, more districts have been created in Northern and Eastern Uganda than other regions. For example, the percentage increase since 1997 is $166 \%$ in eastern region and 200\% in Northern region (Awortwi \& Helmsing, 2014a).

However, to entice citizens to vote differently after district creation and to divide the opposition, it is not enough just to divide and create new districts. Such a change must go hand in hand with some benefits which would lead to shifting electoral preferences. Why would citizens all of a sudden start withdrawing support from the opposition and shift their support toward Museveni, if before they did not. This points at the idea that citizens 'won' something with the district creation which they did not have before. As a new district takes 
shape, Green (2008) says technical and administrative staff are hired, including a Chief Administrative Officer (CAO), Resident District Commissioner (RDC), among many others.

Importantly also, creation of new administrative units has been necessitated by the desire to bring services closer to the people and have these services delivered in an efficient and effective manner. From an efficiency perspective, it is assumed that the smaller the district, the more easily the services can be provided to the majority of the population since the distance between the service centre and where the people live is reduced (Awortwi \& Helmsing, 2014a). On the other hand, the effectiveness in service provision argument is that the local governments may be able to access better local information and tailor services to the preferences of local citizens (ibid).

Beyond the idea that district creation mainly serves the political survival agenda of the incumbent government, literature has also shown that new districts are sometimes created by central level political elites in order to manage ethnic tensions and thus ensure political stability (Treisman, 2007 cited in Green, 2008; Oviasuyi, Idada \& Lawrence, 2010, Awortwi \& Helmsing, 2014a). In Uganda, president Museveni justifies subdividing districts on ethnic lines basing on the fact that the colonial masters in an effort to create political administrative units lumped people of different ethnic groups together and therefore since many Ugandans vote basing on ethnic considerations and not political ones, it means smaller tribes will be marginalized in politics and administration (Musisi, 2015). Awortwi \& Helmsing (2014a) on their part stress that anecdotal evidence from local government officials showed ethnic tensions in some districts of Yumbe, Hoima and Luwero which culminated in split in order to ease the tensions. For instance, the two authors have argued that the peaceful settlement of these conflicts resulted in the creation of Kibaale from Hoima district and Yumbe from Arua district.

Interestingly, many of the above mentioned 'benefits' yielded by the creation of a new district, are actually reaped at the local level: the creation of additional politico-administrative structures and positions allows for the election of more candidates, representatives and public servants; potential increase and access in service delivery; closer contact between citizens and representatives; ethnic inclusion; ethnic empowerment among others. Such benefits (whether actual or expected, whether true or perceived) may particularly in a context of relative deprivation, entice local actors to pursue the creation of 'their' own district. The creation of new institutional arrangements (such as creating a new district) opens a window of opportunity for those who feel relatively deprived and consider that a change may well yield important benefits. The concept of 'policy entrepreneurs' (Kingdon, 1984) seems relevant here. Policy entrepreneurs are individuals or small teams, willing and able to invest resources, to take risks, to build coalitions of supporters and secure legislative action (Mintrom \& Norman, 2009; Mintrom, 1997). Policy entrepreneurs move in the political arena and are motivated by many different factors (interests such as job security, career promotion, but also personal aggrandizement), but also ideological beliefs, or even because of "love for the game" (Hammond, 2013; Mintrom \& Norman, 2009; Kingdon, 1984). 
Policy entrepreneurs could be in or out of government, in elected or appointed positions, in interest groups or research organizations (Meijerink \& Huitema, 2010; Guldbrandsson \& Fossum, 2009). The interesting feature of the concept of policy entrepreneur is that they can be situated at any level (national, local, international) and in any institutional arena (state, civil society, market). In local contexts, political entrepreneurs can be high-level unelected leaders, such as city managers; elected politicians such as mayors or members of city councils, leaders of established interests groups; or creators of new groups (Scheineder \& Teske, 1992).

Whether or not a policy entrepreneur is successful depends on a couple of things. The level of motivations as explained above is one important element because the higher the stakes, the more motivated and persistent the policy entrepreneur will be. The second element depends on the deployment of resources and effective strategies (Verdjuin 2014; Kingdon, 1984; Guldbrandsson \& Fossum, 2009). But at least as important concerns the political connections, the networks and negotiating skills.

\section{Reconstructing the Creation of Sheema District: Local Policy Entrepreneurs in Action}

The study was mainly conducted in the new district of Sheema and its 'mother' district of Bushenyi ${ }^{2}$. We selected Sheema because the district creation process there was started, driven and achieved by local policy entrepreneurs. At the start of the process, president Museveni himself opposed the split and so did three out of four cabinet ministers from Bushenyi district. The president argued that: 1) because people spoke the same language, there was no need to create an additional district (Sengendo \& Ahimbisibwe, 2010), 2) the government was constrained by the administrative budget (Namutebi, 2007). Added to this, it seems that there was no need to split opposition power bases like in Northern and Eastern Uganda (Awortwi \& Helmsing, 2014a), because Bushenyi district was loyal and supportive of the ruling NRM and president Museveni. For example, election results show that the old district of Bushenyi used to score above national average during presidential elections. As Lambright (2011) stresses, president Museveni in his effort to win a contentious third presidential term in 2006, managed to garner $77 \%$ of the vote in Bushenyi compared to $66 \%$ of the vote nationally. Only a couple of years later, however, in 2010 the president shifted his position and agreed to split Bushenyi district into five districts. (Mazige \& Aruho, 2010). The maps below show the location of Bushenyi district in Uganda, its five ${ }^{3}$ former counties and the study area, Sheema district.

\footnotetext{
${ }^{2}$ Two elite interviews, however, were conducted in Mitooma district because these elites occupied key political positions in Bushenyi district before split.

${ }^{3}$ All the five former counties are now districts thus; Igara county-Bushenyi district; Sheema county-Sheema district; Bunyaruguru county-Rubirizi district; Buhweju county-Buhweju district; Ruhinda county-Mitooma district.
} 


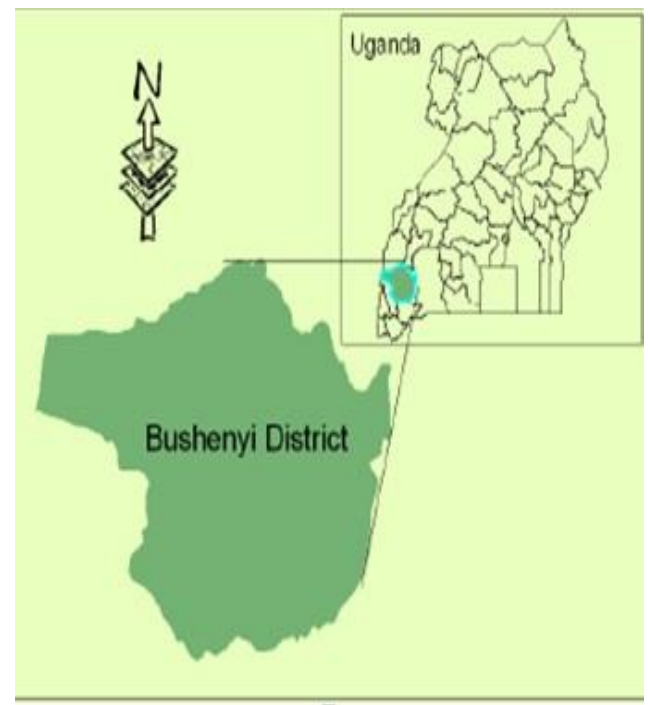

Figure 1. Map of Uganda showing Bushenyi district.

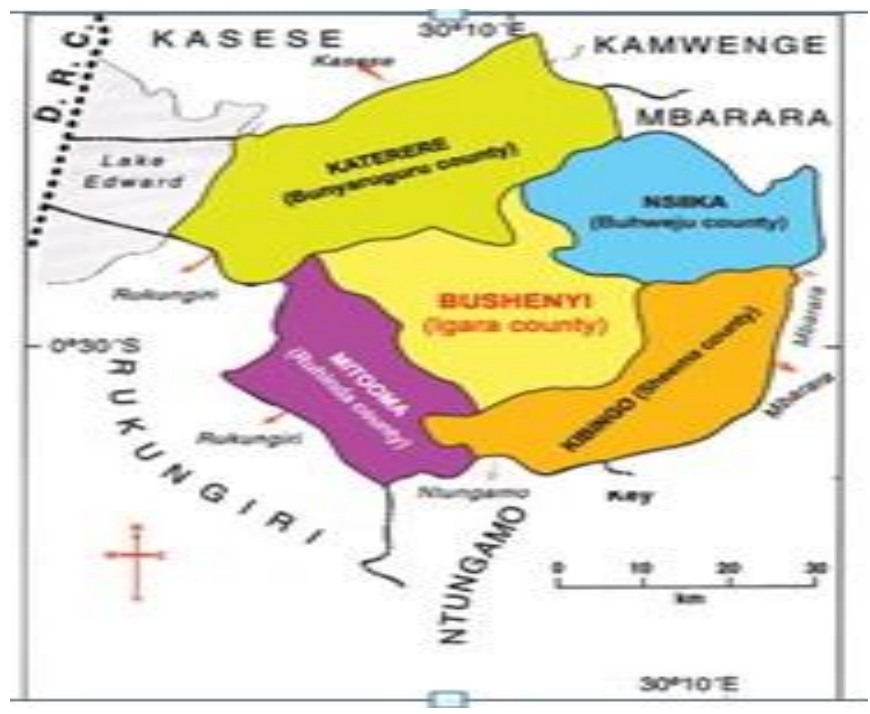

Figure 2. Map of Bushenyi district (before 2010) showing the five counties.

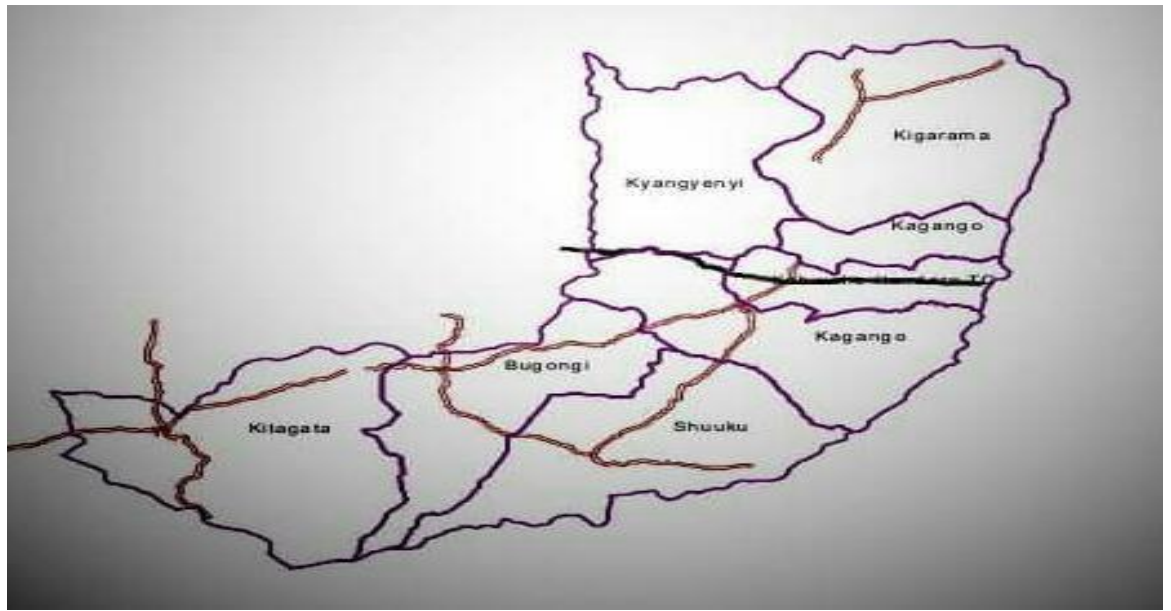

Figure 3. Map of Sheema district showing sub-counties and road network. 


\section{MInstitute Macrothink $_{\text {Int }}$}

Journal of Public Administration and Governance

ISSN 2161-7104

2018, Vol. 8, No. 2

Bushenyi district lies in the south west of Uganda. It is bordered by Rubirizi district to the North West, Buhweju district to the Northeast, Sheema district to the East, Mitooma district to the South and Rukungiri district to the West (See Uganda district map). The district occupies an area of $542.8 \mathrm{~km}^{2}$ (UBOS, 2016).

Sheema district is also situated in south western Uganda and is bordered by Buhweju district to the North, Mbarara district to the East, Ntungamo District to the South, Mitooma district to the Southwest and Bushenyi District to the West. The district occupies an area of $698.6 \mathrm{~km}^{2}$ (UBOS, 2016). The other districts/former counties of Mitooma, Buhweju and Rubirizi do not differ much from Sheema and Bushenyi districts since they fall in the same geographical zone and share same climate.

\section{Research Design}

We conducted key informant interviews with a total of thirty five elites at local and national level but also undertook an extensive review of secondary documents. The table below shows category and number of interviewees.

Table 1. Study Participants

\begin{tabular}{l|l|l}
\hline S/N & Category & Number \\
\hline 1 & Politicians & 24 \\
\hline 2 & Civil servants & 4 \\
\hline 3 & Civil society organization (CSOs) personnel & 3 \\
\hline 4 & Opinion leaders & 3 \\
\hline 5 & Business Persons & 1 \\
\hline 6 & TOTAL & 35 \\
\hline
\end{tabular}

Source: Field data

Purposive and snowball sampling methods were used to select the study respondents. The two non-probability sampling types were necessary to identify knowledgeable people who could refer us to their colleagues. Elite interviewing helped in producing very detailed information on the study object, allowing the researcher to ask follow-up questions in case ambiguous responses emanated and probe further for a deeper understanding of the issues. However, the challenge we encountered in interviewing only elites is that they were at times hard to track down especially when they had retired from active politics or public office. As Mikecz (2012) asserts, gaining access to elites has to be carefully negotiated which can take much longer time and higher costs than non-elite studies.

Also we collected and reviewed documents from the study districts. Documents were needed to reinforce the views obtained through elite interviewing. As Rosanna and Imber (1995) state, the best research on elites combines different forms of methodological approaches to develop the research findings.

\section{Reconstructing the (Perceived) Structural Incentives of District Creation}

The incentives and motivations which push local policy entrepreneurs to pursue (or block for 
that matter) district creation are often located in contextual, structural and institutional features. We therefore reconstruct the socio-economic and political situation of the context to detect these potential incentives and to check the validity of these identified features. We also map the different perceptions of stakeholders to check the relative importance of these structural and institutional factors.

\subsection{Socio-Economic Structure and Incentives for New District Creation}

\subsubsection{Agriculture and Other Economic Activities}

All the five new districts depend on subsistence agriculture as the main economic activity (see table 2 below). For instance in Bushenyi district, Agriculture provides direct employment to $86.7 \%$ of the district population, as well as supplying raw materials to industries ${ }^{4}$. For instance, Sheema district is the leading producer of bananas. Livestock rearing is also an important agricultural activity in all the five districts. We therefore note that all the former counties/ new districts practice agriculture and are involved in many other economic activities with varying degrees. We cannot easily ascertain which district leads others in this particular aspect but we can ably state that Sheema was economically vibrant and therefore well positioned to run a district. According to a former county chief,

Sheema produces bananas in large quantities and at least about twenty lorries of bananas leave Kabwohe and Itendero townships daily to the capital Kampala where there is ready market. In addition, dairy farming is vibrant in Sheema and all these economic potentials could support a new district (interview $9^{\text {th }}$ march 2016).

\subsubsection{Education and Health Facilities}

Bushenyi district has a private university, the Kampala International University. Additionally, it has a technical school, the Uganda Technical College-Bushenyi and a number of good performing schools (Mazige \& Aruho, 2010). Sheema district on the other hand has a private university at Kabwohe, the Ankole Western University and a number of good secondary schools. Although the other districts of Mitooma, Rubirizi and Buhweju have secondary and primary schools (both private and government aided) and some technical schools, none has a university. Buhweju district has the poorest schools (Mazige \& Aruho, 2010).

In terms of health services, Bushenyi district has three privately owned hospitals (ibid). Sheema district on the other hand has a government hospital, the Kitagata government hospital and a number of health centres. None of the remaining districts has a hospital but only health centres.

The presence of all the above social infrastructure demonstrates that Sheema county was

\footnotetext{
${ }^{4}$ Republic of Uganda: Ministry of Agriculture, Animal industry and Fisheries; Bushenyi district.

http://www.agriculture.go.ug/index.php?page=districtsandsph=215andsubpage=Bandeconom icactivities $2=$ true
} 
better placed than most of the other counties to manage a district of its own. A former Mayor argued that,

the existence of tertiary institutions in the county meant that we would produce local professionals to run a district. In other words, Sheema County had potential for local manpower production that would run the new district (interview $14^{\text {th }}$ march 2016).

\subsubsection{Road Infrastructure}

Bushenyi, Sheema and Rubirizi districts have a tarmac road passing through them, the Mbarara-Kasese high way whereas the rest of the districts do not have tarmac access. Sheema district amongst all can be rated as one with the best road network (Mazige \& Aruho, 2010). This has boosted the economic activities in the district. As such in terms of road infrastructure and in comparison with the other counties, Sheema had the basic infrastructure to kick start a new district.

Table 2 below gives a summary of some of the socio-economic indicators of these new districts/former counties. According to the table, apart from Igara County (which housed 'mother'-Bushenyi), Sheema county was superior in most of the socio-economic indicators when compared to the other counties before 2010 and after. For instance, the district has the highest percentage of people using electricity for lighting, the highest literacy rate and has the smallest percentage of people depending on subsistence agriculture. It also has the highest number of people with clean water coverage and has the least number of people who depend on less than two meals a day $(6.9 \%)$.

Table 2. Summary socio-economic indicators of the five districts/former counties

\begin{tabular}{|c|c|c|c|c|c|c|c|c|c|c|c|c|c|}
\hline \multicolumn{8}{|c|}{ Some indicators before 2010} & \multicolumn{6}{|c|}{ Some Indicators after 2010} \\
\hline $\mathbf{S} / \mathbf{N}$ & District & $\begin{array}{l}\text { Population } \\
1991\end{array}$ & $\begin{array}{l}\text { Population } \\
2002\end{array}$ & $\begin{array}{l}\text { Land } \\
\text { area in } \\
\text { Sqkm }\end{array}$ & $\begin{array}{l}\text { Population } \\
\text { density } \\
2002\end{array}$ & $\begin{array}{l}\text { Gov't } \\
\text { Hospital }\end{array}$ & $\begin{array}{l}\text { Tarmac } \\
\text { road }\end{array}$ & $\begin{array}{l}\text { Population } \\
2014\end{array}$ & $\begin{array}{l}\% \\
\text { Literacy } \\
\text { rate }\end{array}$ & $\begin{array}{l}\% \\
\text { Household } \\
\text { using } \\
\text { electricity } \\
\text { for } \\
\text { lighting }\end{array}$ & $\begin{array}{l}\% \\
\text { Dependent } \\
\text { on } \\
\text { subsistence } \\
\text { agriculture }\end{array}$ & $\begin{array}{l}\% \\
\text { Householdwith } \\
\text { protected } \\
\text { water source }\end{array}$ & $\begin{array}{l}\% \text { of } \\
\text { People } \\
\text { having } \\
\text { less } \\
\text { than } 2 \\
\text { meals } \\
\text { a day }\end{array}$ \\
\hline 1 & Bushenyi & 160,982 & 205,671 & 845.3 & 243.3 & $x$ & $\sqrt{ }$ & 234,443 & 80.3 & 19.6 & 67.1 & 58.3 & 7.8 \\
\hline 2 & Sheema & 153,009 & 180,234 & 698.6 & 257.9 & $\sqrt{ }$ & $\sqrt{ }$ & 207,343 & 80.2 & 18.2 & 73.7 & 57.8 & 6.9 \\
\hline 3 & Buhweju & 55,534 & 82,881 & 750.8 & 110.4 & $x$ & $\times$ & 120,720 & 70.3 & 7.9 & 89.6 & 49.3 & 8.9 \\
\hline 4 & Mitooma & 13,4251 & 160,802 & 543.9 & 295.6 & $\times$ & $\times$ & 183,444 & 74.1 & 10.4 & 81.6 & 48.2 & 9.0 \\
\hline 5 & Rubirizi & 75,361 & 101,804 & 1096.3 & 92.8 & $x$ & $\sqrt{ }$ & 10,963 & 69.5 & 11.6 & 81.6 & 55.5 & 9.7 \\
\hline
\end{tabular}

Sources: Extracted from UBOS, 2002 and 2014 \& Field data

The above evidence seems to suggest that Sheema county was and still remains relatively well-off compared to others.

In terms of economic vibrancy, interviews with a former county chief, district chairman and district councilor from Sheema district also revealed that most of the big weekly and monthly 
markets in Bushenyi district were based in Sheema County. These markets generated a lot of local revenue to Bushenyi district. As such Sheema seemed to have acquired a superior level of economic vibrancy. Added to this, Sheema County is also a pioneer when it comes to banking and (micro) finance enterprises. Companies such as Pride microfinance, Muhame microfinance, and the Stanbic bank had offices in Sheema. Other counties apart from Igara did not have these levels of economic vibrancy.

This economic vibrancy also implied that they most probably contributed relatively more to the treasury of Bushenyi district. Interviews with two former senior politicians (Former county chief and a Local council five $\left(\mathrm{LCV}^{5}\right)$ chairman) and all the five district councilors we interviewed from Sheema district revealed that economically, the biggest revenue in the treasury of Bushenyi district had its source in Sheema County. A former staff member in finance department, Bushenyi district further revealed that,

Kagango Sub County in Sheema paid more revenue than other sub-counties of Bushenyi from her monthly markets. Kitagata and Kagango markets remitted to Bushenyi district treasury more market dues than some sub-counties of Bushenyi (interview, $27^{\text {th }}$ April, 2017).

In sum, the above seems to suggest that (before 2010) Sheema County compared to most of the other counties was relatively better off. It had more socio-economic resources, more services and more industry among others. It was also a main contributor to the treasury of Bushenyi district. Given the relative affluent socio-economic status of Sheema and its weight in contributing to the treasury of Bushenyi district, it might seem plausible to believe that this status in part fed the desire to heed for an independent district.

In all likelihood, the idea that district creation would lead to improved services, might not have played a major role in this case. Since Sheema county was much better than most of its neighboring counties such as Buhweju and Bunyaruguru (often referred as hard to reach) the argument of marginalization in social service delivery did not form much of the debate. Instead the argument was that;

the level of social service delivery in Bushenyi district as a whole remained a big challenge due to population outstripping the capacity of staff supported by the central government on the district quota basis resulting into poor performance for those officials. (Former Mayor, Interview $14^{\text {th }}$ March, 2016).

This implies therefore that some policy entrepreneurs in Sheema County wanted a smaller administrative unit with a smaller population that would guarantee more benefits from the central government. Not unsurprisingly, the socio-economic rationale for the split did raise

\footnotetext{
${ }^{5}$ The local government system in Uganda is comprised of a five-tier structure from LCI to LCV (See section 3(4) of the LGA).
} 
some negative reactions, particularly in Bushenyi given that the latter was partly dependent on Sheema for local revenue.

\subsection{Socio-Political Structures}

\subsubsection{Partisan Preferences}

In Bushenyi district, Uganda People's Congress (UPC) was the dominant political party in the early 1980s under the Obote II government ${ }^{6}$ and most of the top leaders in the district and generally Ankole region were UPC ${ }^{7}$. In 1986 when NRM took over power, Bushenyi district shifted support to the new government. Lambright (2011) confirms this assertion when she says, the population of Bushenyi like that of other districts in western Uganda tends to strongly support president Museveni and the Movement (NRM). To clearly demonstrate this support, table 3 below gives a summary of the 1996 presidential election results (for NRM candidate against others) while table 4 gives the 2001 presidential election results for Museveni (NRM) and his main challenger, Kiiza Besigye (FDC) in all the counties that formed Bushenyi district.

Table 3. The 1996 Presidential elections results

\begin{tabular}{l|l|l|l}
\hline County & $\begin{array}{l}\text { Museveni } \\
\text { Yoweri (NRM) }\end{array}$ & $\begin{array}{l}\text { Mayanja } \\
\text { Muhammad } \\
\text { Kibirigye } \\
\text { (Justice Forum) }\end{array}$ & $\begin{array}{l}\text { Ssemogerere Kawanga } \\
\text { (Democratic Party) }\end{array}$ \\
\hline Buhweju & 24485 & 54 & 251 \\
\hline Bunyaruguru & 32584 & 430 & 472 \\
\hline Igara & 60836 & 415 & 3,638 \\
\hline Ruhinda & 57660 & 234 & 596 \\
\hline Sheema & 64742 & 751 & 1582 \\
\hline Total & 240,307 & 1884 & 6539 \\
\hline
\end{tabular}

Source: Electoral Commission 1996

Table 4. The 2001 Presidential elections results (\%)

\begin{tabular}{l|l|l}
\hline County & Museveni (NRM) & Besigye (FDC) \\
\hline Buhweju & 91.1 & 22.9 \\
\hline Bunyaruguru & 83.9 & 21.4 \\
\hline Igara & 75.7 & 7.7 \\
\hline Ruhinda & 74.6 & 23.8 \\
\hline Sheema & 77.7 & 15.1 \\
\hline
\end{tabular}

Source: Electoral Commission 2011

From the tables above, it is clearly observed that NRM candidate dominated in all the five former counties/districts. As such in splitting Bushenyi district, it was not all about splitting opposition power bases as was the case in northern Uganda (see Helmsing and Awortwi,

${ }^{6}$ Dr. Milton Obote was Uganda president from 1966-1971 and again from 1980-1985.

${ }^{7}$ http://www.elections.co.ug/new-vision/election/1415006/analysis-departure-upc-ankole-voti ng-patterns 
2014a) but other socio-economic and political considerations.

Between 1980 and 1989, Sheema electoral candidates and local policy entrepreneurs had expressed discontent over the fact that the position of LCV chairperson had never been granted to them. LCV position had been taken by Igara county in that period (See table 5 below). In 1989, however, Sheema County managed to win the position (as explained later below) and held it until 2001. Again, between 2001-2011, the position was won and occupied by a candidate from Sheema though he was Catholic from an Anglican dominated county ${ }^{8}$.

Table 5. Representation of LCV Chairperson, Bushenyi District

\begin{tabular}{l|l|l|ll}
\hline Period & $\begin{array}{l}\text { County of Origin of } \\
\text { the } \\
\text { Chairperson }\end{array}$ & $\begin{array}{l}\text { Religious } \\
\text { Affiliation }\end{array}$ & Political Party Affiliation \\
\hline $1980-1985$ & Igara & Anglican & UPC \\
\hline $1987-1989$ & Igara & Anglican & $\begin{array}{l}\text { UPC, but had changed to } \\
\text { Democratic Party (DP) }\end{array}$ \\
\hline $1989-2001$ & Sheema & Anglican & NRM \\
\hline $2001-2011$ & Sheema & $\begin{array}{l}\text { Catholic } \\
\text { ("Immigrant") }\end{array}$ & NRM \\
\hline
\end{tabular}

Source: Field data

\subsection{Incentives for New District Creation Emanating from the Socio-Political Structure}

\subsubsection{The 1989 LCV Elections and Formation of Sheema District}

Interviews with a former county chief and a former district councilor revealed that in 1989, Sheema County managed to win the position of LCV chairperson because they sought some electoral support from Kajara County ${ }^{9}$. As such, Sheema overwhelmingly supported the Kajara County's woman candidate to become the first national woman member of parliament for Bushenyi district in the National Resistance Council (NRC). In turn, Sheema's candidate for LCV seat was greatly supported by the people of Kajara and he defeated the opponent. Although Sheema won the position, local policy entrepreneurs in the county felt having their own district would be a better move than struggling for political positions in Bushenyi district.

Related to perceived political exclusion, a former Mayor said,

Sheema county was left out in the distribution of scholarships coming to the district, tenders and many other opportunities especially from the international community (interview $10^{\text {th }}$ March 2016).

To him, many of these opportunities went to Igara county. It was this feeling of marginalization that some policy entrepreneurs in Sheema County opposed which culminated in the demands for a district of their own.

\footnotetext{
${ }^{8}$ Sheema district is $75 \%$ Anglican (Amanyisa, 2016).

${ }^{9}$ It was initially part of Bushenyi district but was cut off in the early 1990s to form the new district of Ntungamo
} 


\subsubsection{The 2001 and 2006 LCV Elections and Formation of Sheema District}

In 2001, the electorate had to decide on the next LCV chairperson for Bushenyi district. The outgoing chairman being a born of Sheema county and an Anglican, some local policy entrepreneurs in the county wanted to consolidate power by retaining the seat as a county. On the other hand, however, the media reported that the Bushenyi district members of parliament had held a meeting in the capital Kampala in which they agreed to support a Catholic candidate to balance religion in the district leadership because the outgoing Chairman was Anglican ("Museveni Cautions Sheema", 2002).

Interviews with two district councilors from Sheema district and a former council speaker revealed that the incumbent chairperson himself had preferred an Anglican successor. Consequently, faced with a Catholic opponent, the outgoing chairman and his team quickly looked for and fronted an Anglican candidate. Unfortunately, due to poor preparations, he lost the election (Interview, former council speaker 15 ${ }^{\text {th }}$ March 2016).

In the 2006 elections, Anglicans and Catholics again silently conflicted over the LCV position. However, interviews revealed that President Museveni intervened and as a solution to the impasse between the two groups, he opted to withdraw the Anglican candidate and offered him an ambassadorial job to Germany. The Catholic candidate remained with no serious opponent and he easily won the position of Bushenyi district chairman (interview, former district chairman $12^{\text {th }}$ march 2016). Some of the policy entrepreneurs in Sheema County were unhappy with the developments and accordingly this is one of the reasons why they started demands for their own district.

\subsubsection{Gains Expected and Formation of Sheema District}

Given the multiple potential advantages (e.g. job creation, improved monitoring and supervision in a smaller territory, increased political representation, increased number of university students on quota system among others), it is plausible to assume that most Sheema policy entrepreneurs would rally behind the idea of an independent Sheema district. However, a former MP but also Minister argued that,

those who expected the benefits were largely local elites such as political leaders and civil servants who aimed at fulfilling their needs without considering the needs of the poor people (interview $19^{\text {th }}$ April 2016).

Further, the split of Bushenyi district was greatly influenced by events in the neighboring district of Mbarara. After split of Mbarara district in 2006, the new districts were realizing many benefits. For instance, one of the current district chairmen stated that,

we realized that Mbarara district after split had a lot of benefits at her disposal including quota sharing of resources in education, National agriculture advisory services(NAADS) among others and Bushenyi district was missing out (interview 2nd May 2016).

As an example, the chairman stressed that the four districts carved out of Mbarara district combined now send forty four students to public universities on quota system up from eleven 
students. This would too mean that the five new districts in Bushenyi would send fifty five students to public universities up from eleven.

\section{Blocking the Split: The Socio-Economic and Political Considerations}

\subsection{Perceived Socio-Economic Dependence and Revenue Loss}

Economically, Bushenyi district collected a lot of local revenue from Sheema County especially from Graduated Tax (GT) and markets and the split of the district would mean a big loss to the district. However, it should be recalled that the largest source of this local revenue, the GT was abolished in 2005. This therefore reduced the amount of revenue Bushenyi district was collecting from its counties. With loss of revenue from GT, Bushenyi district would not wish to lose more. This explains why the district leadership and other elites from Igara county were opposed to the split of the district.

All in all, we note that because of the strong socio-economic status Sheema county enjoyed, some of the local policy entrepreneurs in the county felt it was high time they split from Bushenyi district and managed their own affairs. This in turn of course raised some discontent within Bushenyi district given their partial dependence on Sheema for local revenues.

\subsection{Political Power Losses}

The split of Bushenyi district would further mean loss of political power among some politicians especially Ministers and MPs from the region. Bushenyi district because of its relatively big size commanded some influence and bargaining power at the national level (see also Ahimbisibwe, 2007). Politicians from the district used to speak and engage the national political elites as a block and some had become powerful as individuals. As such, splitting the district would mean reducing the geographical areas of influence for these politicians thus reducing their political power. As such, these politicians opposed the split of Bushenyi district.

In reference to how powerful some politicians had become in the district, one of the current district chairmen stated that,

the former minister for local government and MP, Ruhinda county was a dominant power in Bushenyi and took himself as the only 'bull in the kraal $^{\prime 10}$. He once referred to himself as the 'lion' of Bushenyi. He was a power broker and used to feed the president on lies for selfish reasons (Interview $2^{\text {nd }}$ May 2016).

From the above assertions, we note that splitting Bushenyi district would automatically reduce the power of these politicians. Indeed, after 2010 the powers of the former MP and Minister from Ruhinda County reduced as he could no longer influence politics in 'Greater Bushenyi' but was now confined to his home district of Mitooma.

\footnotetext{
${ }^{10}$ In addition to being Minister for local government and MP for Ruhinda county, he was also the NRM chairperson Bushenyi parliamentary group.
} 
Important to note is that Bushenyi district had eight MPs at the time of the split process. Four of these doubled as cabinet ministers. Whereas five MPs proposed the split, only three opposed. The only area Woman MP supported the split of the district into at least two more districts and not each county becoming a district ("Why Politicians Fought", 2010).

\section{Agency and Strategy: Strategies Adopted for the Creation of Sheema District}

Some county and national policy entrepreneurs originating from Sheema knew that their demands for a new district would never get attention in the Bushenyi district council unless they had a backing from the lower local governments (LLGs) particularly from the sub county councilors. As such, in one of the meetings at Sheema county headquarters, MPs who had organized and financed the meeting requested all the sub counties (LCIIIs) to convene council meetings so that councilors would vote on the issue of Sheema district.

The table below shows how the different sub county councilors voted on the issue of Sheema district for which data was available. However, Kabwohe-Itendero town council had voted on the issue earlier in the year 2005.

Table 6. Results of the Vote on Creation of Sheema District

\begin{tabular}{l|l|l|l|l|l}
\hline \multirow{2}{*}{ Date } & \multirow{2}{*}{ Sub county } & \multirow{2}{*}{$\begin{array}{l}\text { Total number } \\
\text { of councilors }\end{array}$} & \multicolumn{3}{|c}{ Votes } \\
\cline { 4 - 6 } & & & Yes & No & Abstained \\
\hline $4 / 5 / 2005$ & \multirow{2}{*}{$\begin{array}{l}\text { Kabwohe-Itendero } \\
\text { town council }\end{array}$} & 14 & 14 & - & - \\
\hline $24 / 8 / 2006$ & Kitagata & 15 & 15 & - & - \\
\hline $28 / 8 / 2006$ & Shuuku & 11 & 10 & 01 & \\
\hline $5 / 9 / 2006$ & Kigarama & 16 & 10 & 0 & 06 \\
\hline $7 / 9 / 2006$ & Kyangyenyi & 16 & 10 & 0 & 06 \\
\hline TOTAL & & $\mathbf{7 2}$ & $\mathbf{5 9}$ & $\mathbf{0 1}$ & $\mathbf{1 2}$ \\
\hline
\end{tabular}

Source: Field data

Table 6 above clearly shows that the issue of creating a new district was largely supported by majority sub county councilors. As such, equipped with these figures the district councilors from Sheema and other policy entrepreneurs in the county had a strong backing to engage Bushenyi district council for their own district.

Further in the initial stages, some local policy entrepreneurs in Sheema County opted for the formation of an alliance with the neighboring Buhweju County so that the two counties would demand a district as one entity. Interviews with a former Sheema county chief and a former district councilor from Kitagata sub county revealed that two factors were considered for this alliance: one was to boost population numbers in Sheema county and second was to solicit for the support of Buhweju county councilors in the Bushenyi district council.

In light of the above, a committee of three people was formed and tasked to travel to Buhweju County and negotiate with the leadership. Interviews with three respondents at different times and places in Sheema district (a former county chief, a former Mayor and a former councilor) revealed that the composition of the committee was carefully thought through. 
i) An elder from Sheema county for he had served as a head teacher in one of the schools in Buhweju.

ii) A former Sheema county chief for he had worked with a colleague from Buhweju County who worked in a similar capacity.

iii) An LCV councilor from Sheema county for he was a catholic and Buhweju county is predominantly catholic (See Mugasha, 2016).

However, in discussion with one of the committee members, it was revealed that the Buhweju county council refused to attend to the delegates. According to this source and all the five district councilors from Sheema district we interviewed, the policy entrepreneurs opposed to the split had already visited Buhweju County and influenced the leadership (propaganda). As such, the leadership in Buhweju County opted to demand for their own district. Accordingly, the first strategy had failed but brought Buhweju county on board as a pro-Bushenyi district split county.

Another strategy was the formation of a mobilization committee bigger than the one mentioned earlier that had traveled to Buhweju County. Importantly, the general meeting to address the question of the new district was held on $26^{\text {th }}$ January 2005 at Sheema county headquarters. The meeting set up a nine member committee to plan on how a new district could be realized (Former district chairman but also presidential advisor, Interview $12^{\text {th }}$ March 2016). The committee co-opted more members as the process went on.

Besides the two mobilization committees, a number of other individuals and groups of individuals continued to mobilize for a new district. These included councilors at different levels, chairmen of the different local councils, members of parliament, cabinet ministers from Sheema County, civil servants among others. For instance interviews with one of the former LCIII chairpersons, Bugongi Sub County and a sub county councilor revealed that chairmen and councilors greatly mobilized for the new district especially before the minister of local government (on request of the president) visited the area to oversee sub county council resolution making exercise for new district creation on.

I had to make sure, the councilors and local people attended the meetings but also were positive on the issue. So we had to hold preparatory meetings and planned accordingly (Former LCIII chairman, interview $3^{\text {rd }}$ May 2016).

Continuous lobbying of President Museveni and other central political actors by policy entrepreneurs from Sheema county was another strategy. A former Mayor Kabwohe-Itendero town council revealed that:

As Sheema people, we are vocal, economically well off, highly educated and we have a couple of senior presidential advisors, senior police officers and cabinet ministers in government who could lobby for us (interview $14^{\text {th }}$ March 2016).

The implication here is that it was easier for the local policy entrepreneurs in Sheema to lobby from the President and also form alliances with national political elites since they were 
well represented at the national level. Sheema county had one cabinet Minister at the time in the NRM government but together with MPs from the area they played a very crucial role in the realization of the new district. For instance MPs financed most of the meetings that took place at the county headquarters (District councilor, interview 2nd May 2016) but also lobbied a lot. Additionally, the coordination between national legislators, ministers hailing from Sheema county and the local policy entrepreneurs was good and this partly helped in the realization of the intended objective.

Formalization of the new district creation demands in the Bushenyi district council was yet another strategy. Interviews with one of the former LCV chairmen Bushenyi district and a former female district councilor from Kitagata Sub County, revealed that as the process went on, some local policy entrepreneurs in Sheema felt it was high time they formalized their demands in the Bushenyi district council. As such, on $24^{\text {th }}$ September 2006, the policy entrepreneurs in Sheema wrote to the speaker Bushenyi district council requesting him to endorse on the order paper the request for the establishment of Sheema district. Later, on $24^{\text {th }}$ November 2006, the motion for the establishment of Sheema district was tabled in the council.

After the above formalization process, it was now important for Sheema policy entrepreneurs to mobilize councilors from the other counties to support the split in the district council. According to a former Mayor, Kabwohe-Itendero town council who also served as a district councilor at the time, mobilizing other councilors was not a difficult task because ,

all the councilors had many job expectations in the respective new districts as they would serve as council ministers or speakers (Former district council Speaker, interview 15 ${ }^{\text {th }}$ March 2016).

As such, deep down in their hearts, they supported the move but because of external influences, they seemed to oppose. According to a former Mayor,

most of the opposing councilors were not vocal in the district council for fear of reprimand by the electorate and with time they shunned some of the meetings in the district to deliberate on the issue of splitting Bushenyi (Former mayor interview $10^{\text {th }}$ March 2016).

It is important to note that Buhweju and Bunyaruguru councilors were already in support of the split as their counties were lagging behind others. They thought by obtaining a district of their own, they would benefit more. In Mitooma, many of the councilors supported the move although their area MP was highly opposed to the move. Importantly, one of the district councilors from Mitooma served as the vice chairperson of Bushenyi district and supported the split. He played an important role in convincing his colleagues to support the move. Councilors from Igara county later joined the pro-split group and in the words of a former mayor,

With time, many of the Igara county councilors joined the pro-split group because of the expected benefits (interview 10 ${ }^{\text {th }}$ March 2016). 
Thus, on $10^{\text {th }}$ January 2007, the Bushenyi council resolved to create new districts out of Bushenyi. After the district council resolution to form new districts was passed, it was now the duty of the LCV chairman to formally write to the Minister of local government informing him about the resolutions as required by law. It is important to note, however, that the Chairman LCV at the time together with his executive were initially opposed to the split of the district but in the words of one former district councilor,

they were overtaken by events and since they were at the mercy of voters, they finally supported the split (interview 10 $0^{\text {th }}$ March 2016).

As such, the chairman wrote to the Minister of local government informing him about the district council resolutions.

On $14^{\text {th }}$ April 2009, a visitation committee from Sheema county composed of 19 people went to the ministry of local government. The committee which was headed by both the former LCV chairman but also senior presidential advisor and MP Sheema North of the time presented their demands for a new district to the (new) Minister ${ }^{11}$.

The Minister in response promised to send our request to the presidency, cabinet and parliament (interview, a committee member $9^{\text {th }}$ March 2016).

Importantly to note also is that timing was very crucial. Local policy entrepreneurs in Sheema knew that their demands for a new district would only make sense towards an election time. As noted earlier 'Greater Bushenyi' was pro-NRM. According to all the five district councilors from Sheema district we talked to, the president risked losing votes if he had not granted their wishes. That is why pressure mounted towards the 2011 general elections.

Lastly in 2010, president Museveni who had visited Bushenyi twice over the issue of splitting the district decided that the issue should be sent back to the sub counties for local councilors to make resolutions on it (Former district councilor interviews, $10^{\text {th }}$ March 2016). He too sent the two ministers of local government to oversee the resolution making process. The overwhelming response from the sub counties and the positive report from the two ministers in favour of a new district made the president to grant the people's wish and Bushenyi was split into five districts in the same year.

\section{Conclusion}

The paper has clearly demonstrated that Sheema district unlike other new districts in Uganda provides a deviant case in a sense that whereas the central political elites (policy entrepreneurs) especially president Museveni and most of the cabinet ministers from Bushenyi district were opposed to the split of the district, policy entrepreneurs in Sheema County insisted on having their own district. The major factors that made it possible for the

\footnotetext{
${ }^{11}$ The former minister of local government hailed from Bushenyi district and was opposed to the split of the district. His removal from the local government docket and the appointment of a new Minister in 2009 was seen as an opportunity by Sheema elites to make their case, for he was seen as a stumbling block.
} 
local policy entrepreneurs in Sheema to realise their goal are a) the existence of some influential central political elites hailing from Sheema county such as MPs, senior presidential advisors and a cabinet minister among others who worked closely with the local policy entrepreneurs at the county level to bring about the desired policy change; b) the timing given that the demands gained momentum at a time when the country was going into the 2011 general elections c) high level of organisation. These combined with high mobilization and coordination capabilities of the local policy entrepreneurs among other factors made it possible for the creation of Sheema district in 2010. Therefore, whereas literature demonstrates that district creation is majorly driven by the central government elites for political survival reasons, our study has shown that local actors can play a critical role in the process.

\section{References}

Ahimbisibwe, C. (2007, August 6). Kabwegyere raps MP on Bushenyi split. New vision. Retrieved from http://www.newvision.co.ug/new_vision/news/

Amanyisa, Z. (2016, June 5). Sheema's Anglican -Catholic power race. The Daily Monitor. Retrieved from http://www.monitor.co.ug/Magazines/PeoplePower/

Awortwi, N., \& Helmsing, A. H. J. (Bert) (2014a). In the name of bringing services closer to the people? Explaining the creation of new local government districts in Uganda. International Review of Administrative sciences, 80(4), 766-788. https://doi.org/10.1177/0020852314533455

Awortwi, N., \& Helmsing, A. H. J. (Bert) (2014b). Behind the façade of bringing services closer to people: The proclaimed and hidden intentions of the government of Uganda to create many new local government districts. Canadian Journal of African Studies, 48(2), 297-314. https://doi.org/10.1080/00083968.2014.905260

Electoral Commission. (1996). Presidential election results. Kampala, Uganda: Author. Retrieved from http://www.ec.or.ug/sites/Elec_results/Nat_Res_1996.pdf

Electoral Commission. (2011): Presidential election results. Kampala, Uganda: Author. Retrieved from http://www.ec.or.ug/?q=content/2011-general-election

Green, E. (2008). District creation and decentralization in Uganda. (Crisis States Research Centre, No. 24). Retrieved from http://www.lse.ac.uk/international-development/

Green, E. (2010). Patronage, District Creation and Reform in Uganda. Studies in comparative International development, 45(1), 83-103. https://doi.org/10.1007/s12116-009-9058-8

Grossman, G., \& Lewis, J. (2014). Administrative Unit Proliferation. American Political Science Review, 108(1), 196-217. https://doi.org/10.1017/S0003055413000567

Guldbrandsson, K., \& Fossum. (2009). An exploration of the theoretical concepts policy windows and policy entrepreneurs at the Swedish public health arena. Health promotional international, 24(4), 434-444. https://doi.org/10.1093/heapro/dap033 
Hammond, R. D. (2013). Policy Entrepreneurship in China's Response to Urban poverty. The policy studies journal, 41(1), 119-146. https://doi.org/10.1111/psj.12005

Kasara, K. (2006). Ethnic Beachheads and Vote Buying: Explaining the Creation of New Administrative Districts in Kenya, 1963-2001. Paper presented at the annual meeting of the American Political Science Association, Marriott, Loews Philadelphia, and the Pennsylvania Convention Center, Philadelphia, 2013-12-16.

Kingdon, W. J. (1994). Agenda's, Alternatives and public policies. Boston: Little, Brown and co.

Lambright, G. M. S. (2011). Decentralisation in Uganda: Explaining successes and failures in local governance. Boulder and London: First Forum press.

Lewis, J. (2014). When Decentralization leads to Recentralization: Sub-national state transformation in Uganda. Regional and Federal Studies, 24(5), 571-588. https://doi.org/10.1080/13597566.2014.971771

Mazige, J., \& Aruho, P. (2010 April 27). Names for split Bushenyi district contested. Daily Monitor April $27^{\text {th }}$. Retrieved from http://www.monitor.co.ug/News.

Meijerink, S. V., \& Huitema, D. (2010). Policy entrepreneurs and change strategies: Lessons from sixteen case studies of water transitions around the globe. Ecology and society, 15(2), 21. https://doi.org/10.5751/ES-03509-150221

Mikecz, R. (2012). Interviewing elites: Addressing methodological issues. Qualitative Inquiry, 18(6), 482-493. https://doi.org/10.1177/1077800412442818

Mintrom, M., \& Norman, P. (2009). Policy entrepreneurship and policy change. The policy studies journal, 37(4), 649-667. https://doi.org/10.1111/j.1541-0072.2009.00329.x

Mitrom, M. (1997). Policy entrepreneurs and the diffusion of innovation. American Journal of political science, 41(3), 738-770. https://doi.org/10.2307/2111674

Mugasha, C. (2016 February 15). RDC forces Buhweju candidates to shake hands. New vision Retrieved from http://www.elections.co.ug/new-vision/.

Museveni cautions Sheema leaders over religion and leadership. (2002 January 22). New vision 2002. Retrieved from http://www.newvision.co.ug/new_vision/

Musisi, F. (2015 June 15). Creating many districts good, says Museveni. The Daily Monitor, Retrieved from http://www.monitor.co.ug/News/National

Namutebi, J. (2007 January 15). Museveni cautions on Bushenyi district split. New vision, Retrieved from http://www.newvision.co.ug/new_vision/news/

Niringiye, A., Bbaale, J., \& Olowo, P. (2013). District Creation and Primary Education Service Delivery in Uganda. Asian Journal of Humanities and Social Studies, 01(5), 432-437. 


\section{Macrothink}

Journal of Public Administration and Governance ISSN 2161-7104 2018, Vol. 8, No. 2

Oviasuyi, P. O., Idada, W., \& Lawrence, I. (2010). Constraints of local government administration in Nigeria. Journal of social sciences, 24(2), 18-86. https://doi.org/10.1080/09718923.2010.11892848

Rosanna, H., \& Imber, J. B. (1995). Studying elites using qualitative methods. London: Sage.

Schneider, M., \& Teske, P. (1992). Toward a theory of the political entrepreneurial: Evidence from local government, The American political science Review, 86(3), 737-747. https://doi.org/10.2307/1964135

Ssengendo, A., \& Ahimbisibwe, C. (2010 January 11). Museveni cautions Bushenyi leaders. New vision, Retrieved from https://www.newvision.co.ug/news

Treisman, D. (2007). The Architecture of Government: Rethinking Political Decentralization. In: Green, E. (2008). District creation and decentralization in Uganda, (Crisis states Research Centre, No. 24, p.6). Retrieved from http://www.lse.ac.uk/international-

Uganda Bureau of Statistics (UBOS). (2002). The National Population and Housing Census. Kampala, Uganda: Author.

Uganda Bureau of Statistics (UBOS). (2016). The National Population and Housing Census. Kampala, Uganda: Author.

Verduijn, S. (2014). Leaving your mark: Policy entrepreneurs setting the agenda in the Ijsselmeer Area. Delft: Eburon Academic publishers.

Why politicians fought to stop Bushenyi split. (2010 April 28) The Observer. Retrieved from http://www.observer.ug/news-headlines/

\section{Copyright Disclaimer}

Copyright for this article is retained by the author(s), with first publication rights granted to the journal.

This is an open-access article distributed under the terms and conditions of the Creative Commons Attribution license (http://creativecommons.org/licenses/by/4.0/). 